\title{
EMPLOYER OPINIONS ON LIVING WAGE INITIATIVES*
}

\author{
Don Grant and Mary Nell Trautner
}

Why do some contractors oppose living wage ordinances (LWOs) while others do not? Can local government programs that take a more voluntary approach to creating living wages succeed? This article begins to address these questions through surveys of two sets of employers in the same community: a group of contractors subject to an LWO and the other a group of businesses that voluntarily pledged to pay their workers a living wage. Results suggest that contractors oppose such ordinances either because they are incapable of realizing efficiency gains or for purely ideological reasons. Findings also suggest that the only companies to participate in more voluntary programs are those that were already paying their workers a living wage. Implications of these results for the living wage movement are discussed.

\section{Employer Opinions on Living Wage Initiatives}

Over 70 municipalities across the U.S. have adopted living wage ordinances, (LWOs) including such prominent places as Los Angeles, New York, Chicago, and Baltimore. Living wage ordinances are founded on the principle that an honest day's work should be rewarded by an honest day's pay, and local tax dollars should not be used to finance poverty level jobs. These ordinances require, therefore, that workers paid from local government contracts be given a wage that is sufficient for a family of four to live or a wage slightly above the federal poverty level (see Reynolds, 1999; Pollin, 2002). Because LWOs apply only to a small fraction of a community's total workforce, their real purpose is not so much to cure local employment problems as to raise awareness about them and set an example of what constitutes a good corporate citizen.

Extensive research has documented the benefits of LWOs for workers. Studies note, for example, the renewed sense of dignity that employees experience as a result of their pay increases and their ability to move off welfare rolls (e.g., Pollin \& Luce, 1998; Neumark \& Adams, 2000). Much less is known, however, about the contractors subject to LWOs and their opinions of these measures; nor has much research been done on other employers' willingness to pay a living wage. This despite repeated warnings from free market advocates that LWOs are hostile to business and employers should only pay living wages on a voluntary basis (see Employment Policies Institute, 2000). In truth, LWOs 
are consistent with free market principles in that they allow local governments, as consumers, to act on their buying preferences when selecting contractors. In addition, LWOs (unlike minimum wage laws) are voluntary in the sense that no company is required to bid on any government contract. Still, one can legitimately ask why do some contractors oppose LWOs while others do not? And can local government programs that take a more voluntary approach to creating living wages succeed? This article begins to address these questions through surveys of two sets of employers in the same community: a group of contractors subject to an LWO and the other a group of businesses that voluntarily pledged to pay their workers a living wage.

In 1999, the city of Tucson, Arizona adopted an LWO, the first ever passed in a right-to-work state. ${ }^{1}$ Months later, the city's newly elected Republican mayor proposed a Living Wage Club [subsequently renamed the Good Business Partnership (GBP) program] to encourage other local businesses in the city to voluntarily pay their workers a living wage. To join the club, a company must pledge to pay its workers a living wage in the following year (in addition to adopting other "best business practices," including flexible scheduling). The mayor's office recognizes each club member by giving it a special "Good Business Partnership" logo to be displayed on a company's window and letterhead and by listing the company's name on the mayor's website (which has yet to be done). The city's Chamber of Commerce has embraced the mayor's program as a reasonable alternative to the "mandated wage standards" set down by the city's LWO. Local newspapers have also cast doubt on the viability of the LWO, suggesting that most contractors oppose such involuntary measures because of the administrative and financial burdens they impose (Higuera, 2002).

In the summer of 2002, we surveyed the contractors subject to the city's LWO, as well as a randomly selected set of businesses that are members of the mayor's GBP program. We did so to determine: (1) the extent to which these two groups oppose the LWO, (2) what changes they have observed in their workers' performance since participating in their respective living wage programs, and (3) what adjustments they have had to make to pay their workers a living wage. Results from both surveys are reported here.

\section{Context}

As nonstandard work (temporary, subcontracting, day labor) has grown in recent years, individuals have increasingly been placed in work settings where their legal (de jure) and real (de facto) employers differ (Kalleberg, Reskin, \& Hudson, 2000). Such triangular work arrangements expose workers to fundamentally different power dynamics than the standard, bilateral employment relations. As Kalleberg et al. (2000) explain, contract workers are subject to the demands of their de facto employer, but without the hope of security and advancement with these employers that real employees enjoy. Hence, the pay and insurance benefits of nonstandard workers are not subject to the same 
incentives that their de facto employers provide to their real employees. Conversely, the de jure employer is ill prepared to evaluate their employees' performance and has minimal stake in doing so. Consequently, nonstandard workers have little hope of improving their position with their de jure employers by working harder.

Understood in this light, living wage policies are an attempt to call attention to the plight of individuals in nonstandard work. More specifically, there is an attempt by some local governments to alert the public to the vulnerabilities associated with nonstandard work caused by privatization. Living wage ordinances also suggest how such vulnerabilities might be addressed by requiring the real employer (in this case, the city government) to establish pay standards for legal employers (in this case, city contractors).

Local media and chambers of commerce play key roles in debates over living wage initiatives. Invoking conventional economic wisdom, they often question whether exogenous (i.e., policy-induced) wage increases are viable. According to them, LWOs put contractors at a competitive disadvantage and escalate the price of the entire bidding process (see also Employment Policies Institute, 2000). They suggest that the only legitimate and effective wage policies are voluntary ones. For example, they are more supportive of government programs that provide information on the pay practices of companies. Such information, if freely offered by businesses, might create more efficient markets by assisting citizens in their job searches and/or helping them act on their preferences as patrons. $^{2}$ Tucson's GBP program, which seeks to generate positive publicity for companies that pledge to pay a living wage, is an example of such a voluntary approach. $^{3}$

In responding to critics of LWOs, proponents have stressed how the extra earnings workers receive improve their feelings of self-worth, reduce social costs (e.g., reliance on food stamps, publicly provided cash assistance, unemployment insurance), create multiplier effects through increased spending, and counteract the trend toward greater economic inequality (see Bernstein, 2000). However, proponents have neither directly asked contractors and other owners whether they support LWOs or not; nor have they tried to demonstrate the ineffectiveness of other, more voluntary approaches to raising wages. Consequently, they have yet to specify what it is about certain employers that would make them resist living wage measures and why, therefore, LWOs are necessary.

Most of what is known about employers' position on and experiences with paying living wages is inferred from three sources: (1) studies on federal minimum wage and prevailing wage laws (e.g., Card \& Krueger, 1999), (2) a handful of case studies that examine changes in contract costs, employment levels, profits, and productivity experienced by contractors subject to an area's LWO (e.g., Schoenberger, 2000), and (3) the testimonies of private employers who voluntarily pay their workers living wages (Kraut, Klinger, \& Collins, 2000). The basic conclusion drawn from these studies is that employers can absorb pay increases mandated by LWOs through efficiency gains, specifically 
through lower rates of turnover, increased employment stability, and improved worker morale and productivity (Bernstein, 2000).

Yet, whatever potential benefits LWOs might offer employers, we know from anecdotal evidence that not all support these measures. Why this is so has yet to be explored. Is this because of other indirect costs (e.g., compression wage increases and reporting requirements) of which critics of LWOs frequently complain? Is it because the opponents' administrative procedures prevent them from realizing efficiency gains (i.e., are they unable to absorb the costs of paying their workers higher wages)? Or do supporters and opponents have similar indirect costs and administrative procedures, but opponents simply reject LWOs for ideological reasons?

Likewise, researchers have failed to ask what the other employers' opinions about LWOs are. In particular, what do companies that voluntarily pay their workers a living wage think of such ordinances? Might they oppose such measures on ideological grounds? What has been their experience with more voluntary living wage programs? Have they paid more of their workers a living wage as a result of participating in such programs? Or did they pay workers living wages in the first place and therefore participated in these programs because of the good public relations it might create for them?

\section{Methods}

Tucson, Arizona provides a unique natural experiment for determining answers to these questions. Tucson is the only city in the country with both an LWO and a voluntary living wage program. Survey forms were mailed to participants in both programs according to Dillman's "total design method" (Dillman, 1978). We sent a one-page survey form, a cover letter, and flier (along with a self-addressed, stamped return envelope) to each of the 30 businesses subject to the city's LWO and a random sample of businesses affiliated with the mayor's GBP program. ${ }^{4} \mathrm{~A}$ list of city contractors, along with their contact information, was provided by the City of Tucson's Procurement Department. We obtained a complete list of members of the GBP, along with their contact information and basic characteristics, from the mayor's office. This list contained the names of 111 businesses. From this list, we selected a random sample of 60 businesses using a random-number generator.

We received a total of 59 survey responses, 18 of which were from city contractors, and 41 were from those businesses affiliated with the GBP. Of the 60 businesses in the GBP, three are actually not in the program (one dropped out and two had never been in the program), bringing the sample size down to 57 . Thus, the response rate for the GBP survey is $72 \%$. For the LWO survey, we were unable to locate one of the contractors, bringing the sample size down to 28 , and giving us a response rate of $63 \%$. While this may seem a bit low, the response rate for the survey of contractors is in the range of previous surveys of the same population conducted by the city $(58 \%$ and $72 \%)$. The overall response rate for the project came to $68 \% .^{5}$ 
Below we report, in turn, the findings from our surveys of city contractors and members of the GBP program.

\section{Findings}

\section{The City of Tucson's Living Wage Ordinance}

Table 1 provides information about our sample group of contractors and their experiences with the LWO. The first column shows that, on average, contractors employ 127 workers. Approximately four-fifths (79\%) of their employees work full-time and more than half $(55 \%)$ were paid a living wage at the time of the survey. Roughly one-fifth (22\%) of their workers are paid directly from city contracts and therefore are subject to the city's LWO.

In terms of their experiences with the LWO, several contractors report improvements in worker performance. These include improved morale $(39 \%)$, reductions in turnover $(33 \%)$, theft (11\%) and accidents (11\%), and decrease in paid overtime hours paid (6\%), as well as increased productivity (22\%).

Contractors were asked what adjustments they made in order to comply with the LWO. Table 1 indicates that, in most cases, contractors had to implement a wage increase, as only $28 \%$ of their workers subject to the requirements of the LWO were already being paid a living wage. Critics of LWOs frequently complain that these ordinances create administrative nightmares for contractors. Contrary to this argument, Table 1 reveals that less than two-fifths (39\%) of the contractors report that they were forced to change how their payroll is reported. Opponents of LWOs also complain of the wage compression problems they create, that is, employees who do the same type of work as those being awarded a living wage or are accustomed to being paid more than the latter sometimes demand wage increases. Survey results suggest that the problem of wage compression is a real one, but it also affects a smaller percentage of contractors than critics suggest. Only one-third (33\%) of contractors were forced to raise the wages of workers in the same work classification as those paid from city contracts. An even smaller percentage (11\%) was forced to raise the wages of workers in different work classifications than those paid from city contracts. Finally, a large percentage of contractors chose to absorb the additional costs of complying with the LWO. This finding challenges the claims of fiscal conservatives that contractors will simply pass on their additional costs to taxpayers in the form of higher contract bids.

As indicated earlier, since the ordinance was passed, some local newspaper reports had suggested that the majority of contractors oppose it, citing as reasons the burdensome paperwork it created and the friction it produced between employees receiving a living wage and those who do not (i.e., compression problems). Our results suggest that it would be more accurate to say that contractors are evenly split on this issue: of the 18 contractors surveyed, 9 say they oppose the continuation of the living ordinance, while 9 favor its continuation. 
Table 1. Characteristics and Experiences of Living Wage Contractors $(\mathrm{N}=18)^{*}$

\begin{tabular}{|c|c|c|c|}
\hline & $\begin{array}{l}\text { All living } \\
\text { wage } \\
\text { contractors }\end{array}$ & $\begin{array}{l}\text { Living wage } \\
\text { contractors } \\
\text { who oppose } \\
\text { the LWO } \\
(\mathrm{N}=9)\end{array}$ & $\begin{array}{l}\text { Living wage } \\
\text { contractors } \\
\text { who support } \\
\text { the LWO } \\
(\mathrm{N}=9)\end{array}$ \\
\hline \multicolumn{4}{|l|}{ Company characteristics } \\
\hline Average number of employees & 127 & 130 & 118 \\
\hline$\%$ of employees who work full time & $79 \%$ & $82 \%$ & $75 \%$ \\
\hline$\%$ of workers paid a living wage & $55 \%$ & $45 \%$ & $70 \%$ \\
\hline$\%$ of all workers paid directly from city contracts & $22 \%$ & $17 \%$ & $26 \%$ \\
\hline \multicolumn{4}{|l|}{ Observed changes in worker performance } \\
\hline Improved morale & $39 \%$ & $11 \%$ & $66 \%$ \\
\hline Reduction in turnover & $33 \%$ & $0 \%$ & $66 \%$ \\
\hline Reduction in absenteeism & $28 \%$ & $0 \%$ & $56 \%$ \\
\hline Increased productivity & $22 \%$ & $0 \%$ & $44 \%$ \\
\hline Reduction in accidents & $11 \%$ & $0 \%$ & $22 \%$ \\
\hline Reduction in theft & $11 \%$ & $0 \%$ & $22 \%$ \\
\hline Decrease in overtime hours paid & $6 \%$ & $0 \%$ & $11 \%$ \\
\hline \multicolumn{4}{|l|}{ Adjustments made in order to pay workers a living wage } \\
\hline $\begin{array}{l}\text { No pay increase required (i.e., \% of workers } \\
\text { subject to LWO requirements who were } \\
\text { already being paid a living wage) }\end{array}$ & $28 \%$ & $22 \%$ & $33 \%$ \\
\hline Forced to change how payroll is reported & $39 \%$ & $44 \%$ & $33 \%$ \\
\hline $\begin{array}{l}\text { Forced to raise wages of workers in the same work } \\
\text { classification as those paid from city contracts }\end{array}$ & $33 \%$ & $33 \%$ & $33 \%$ \\
\hline $\begin{array}{l}\text { Forced to raise wages of workers in different work } \\
\text { classifications than those paid from city contracts }\end{array}$ & $11 \%$ & $11 \%$ & $11 \%$ \\
\hline Absorbed additional costs of complying with LWO & $66 \%$ & $66 \%$ & $66 \%$ \\
\hline \multicolumn{4}{|l|}{ Opinions about the City's Living Wage Ordinance } \\
\hline Support the continuation of the LWO & $50 \%$ & & \\
\hline
\end{tabular}

* 18 out of 29 contractors surveyed or a response rate of $63 \%$.

That some contractors would oppose the LWO is not especially surprising given that the city's Chamber of Commerce, which continues to try to rescind the ordinance, has portrayed the latter in the media and public hearings as one that is hostile to business. Indeed, what is intriguing is that some contractors would support it all, which raises the question of why some contractors support an LWO while others do not. Is it the case that contractors oppose the ordinance simply because of the additional paperwork and internal friction among workers it creates? Could there be something about how different contractors manage their businesses that prevent them from realizing efficiency gains when operating under the ordinance's living wage requirements? Or do some contractors oppose the ordinance on purely ideological grounds?

The next two columns of Table 1 begin to address these issues by comparing contractors who oppose and support the LWO in terms of their organizational characteristics and outcomes. It shows that, on average, opponents and supporters of the ordinance employ roughly the same number of workers (130 
and 118 , respectively) and hire a similar percentage on a full-time basis (82\% and $75 \%$, respectively). However, opponents pay a considerable smaller percentage of their workers a living wage. To be exact, opponents pay $45 \%$ of their employees a living wage compared to supporters who pay $70 \%$ of their workers such a wage. Interestingly, a slightly higher percentage of supporters' workers are paid directly out of city contracts, suggesting that the ordinance, if anything, has a potentially bigger impact on their personnel operations than the opponents'.

We see that across a number of indicators, supporters have had more positive experiences with the ordinance than opponents. Two-thirds (66\%) of supporters report an improvement in worker morale and a reduction in employee turnover since the LWO was passed. Slightly more than half (56\%) experienced a decrease in absenteeism. Some witnessed an increase in productivity (44\%), a reduction in accidents $(22 \%)$ and theft $(22 \%)$, and a decrease in the number of overtime hours they paid employees (11\%). With the exception of one contractor who observed an improvement in worker morale, none of the ordinance opponents reported an improvement in any of these areas.

Why should opponents and supporters of the LWO have such different experiences with it? It might be, as opponents suggest, that they are hampered by greater paperwork created by the ordinance and this burden spills over into other areas. Contrary to this notion, however, survey findings show that about the same percentage of opponents were forced to change how they reported payroll $(44 \%)$ as those who support the ordinance $(33 \%)$. Also, both sets of contractors were equally affected by compression problems-that is, $33 \%$ of supporters and opponents were forced to raise the wages of workers in the same work classification as those paid from city contracts, and $11 \%$ of supporters and opponents were forced to raise the wages of workers in different work classifications. Hence, two of the factors often cited as reasons for why the ordinance should be abandoned-administrative burdens and wage compression-probably cannot explain why some contractors oppose the ordinance and others do not.

Another possibility is that opponents have smaller operating budgets and therefore the LWO imposes a disproportionate financial burden on them. Unfortunately, only one-fourth of the contractors provided us with information on the size of their operating budgets that would allow us to make this determination. But even if opponents did have smaller budgets, the fact remains that all contractors had the option of passing on the additional costs of complying with the ordinance in the form of a higher bid. And yet, as Table 1 reveals, most opponents $(66 \%)$ declined to exercise this option; that is, they chose to absorb the extra costs of paying a living wage.

Explanations offered by opponents as to why some contractors oppose LWOs, are therefore generally unsupported. This raises the question of what other factors could explain some contractors' resistance. It could be, as some have suggested, that some contractors' managerial practices are too inflexible to allow them to realize efficiency gains. 
Unfortunately, although our survey findings are consistent with this interpretation, our data do not allow us to directly test this explanation. They do, however, point to another possibility that is rarely mentioned in the literature, which is that some contractors may oppose LWOs on purely ideological grounds. Indeed, the fact that nearly a quarter $(22 \%)$ of all contractors who oppose the LWO also paid all of their affected workers a living wage before the ordinance was adopted suggests that some are not against living wages per $s e$ but the idea that pay levels can be mandated by a local government. ${ }^{6}$

\section{The City of Tucson's Good Business Partnership Program}

Of the 18,632 companies operating in the Tucson metropolitan area, 111 have officially joined the GBP program thus far. Together, the latter companies employ 10,092 workers. Expressed as a percentage of the metropolitan area's entire workforce (288,342 employees), roughly 3.5 percent of all workers in Tucson are employed by companies that have voluntarily pledged to pay a living wage. While there may be other companies in the area that pay, or plan to pay their workers a living wage in the area, these are the only ones to date who have come forward and made a public pledge to do so.

Table 2 reports that member companies, on average, employ 85 workers, $86 \%$ of their workers are employed full time, and $95 \%$ of their workers were paid a living wage at the time of the survey. While the latter finding suggests that participants in the GBP program are quite sincere about their commitment to pay a living wage, it nonetheless begs the question of whether this commitment can actually be attributed to the program itself. That is, of the workers who currently receive a living wage in these companies, what percentage were paid a living wage prior to the creation of the mayor's GBP program? Survey results indicate that virtually every worker $(99.4 \%)$ was already being paid a living wage before their company joined the program. This suggests that companies participated in the GBP not with the intent of making real substantive changes to their pay structures, but to enhance their local image.

It is also interesting to note that a majority (66\%) of the companies belonging to the GBP also support the continuation of the city's LWO. This finding suggests that most participants in the program view the two approaches as complementary rather than antithetical, as opponents would have the public believe. $^{7}$ On the other hand, the fact that one-third (33\%) of these bigh-road companies do not support the continuation of the ordinance perhaps speaks again to the role that ideology plays in determining managers' opinions on living wage initiatives. That is, it suggests that some owners are not so much opposed to paying living wages as they are to the idea that local communities have the right to impose pay standards on private employers.

Not surprisingly, because companies were already paying their employees a living wage before the mayor's program was created, membership in the GBP has not had an appreciable effect on these companies' performance. As Table 2 reveals, only $7.3 \%$ have witnessed an improvement in worker morale. Less than 
Table 2. Characteristics and Experiences of Participants in the Good Business Partnership Program $(\mathrm{N}=41)^{*}$

\begin{tabular}{|c|c|c|c|}
\hline & $\begin{array}{l}\text { All GBP } \\
\text { members }\end{array}$ & $\begin{array}{l}\text { GBP members } \\
\text { who oppose } \\
\text { the LWO } \\
(\mathrm{N}=14)\end{array}$ & $\begin{array}{l}\text { GBP members } \\
\text { who support } \\
\text { the LWO } \\
(\mathrm{N}=27)\end{array}$ \\
\hline \multicolumn{4}{|l|}{ Company characteristics } \\
\hline Average number of employees & 85 & 161 & 46 \\
\hline$\%$ of employees who work full time & $86 \%$ & $88 \%$ & $85 \%$ \\
\hline$\%$ of workers paid a living wage & $95 \%$ & $98 \%$ & $93 \%$ \\
\hline$\%$ of all workers paid directly from city contracts & $0 \%$ & $0 \%$ & $0 \%$ \\
\hline \multicolumn{4}{|l|}{ Observed changes in worker performance } \\
\hline Improved morale & $7.3 \%$ & $0 \%$ & $11 \%$ \\
\hline Reduction in turnover & $4.9 \%$ & $0 \%$ & $7.4 \%$ \\
\hline Reduction in absenteeism & $4.9 \%$ & $0 \%$ & $7.4 \%$ \\
\hline Increased productivity & $4.9 \%$ & $0 \%$ & $7.4 \%$ \\
\hline Reduction in accidents & $0 \%$ & $0 \%$ & $7.4 \%$ \\
\hline Reduction in theft & $0 \%$ & $0 \%$ & $0 \%$ \\
\hline Decrease in overtime hours paid & $4.9 \%$ & $0 \%$ & $7.4 \%$ \\
\hline \multicolumn{4}{|l|}{ Adjustments made in order to pay workers a living wage } \\
\hline $\begin{array}{l}\text { No pay increase required (i.e., \% of workers paid a } \\
\text { living wage before joining the GBP) }\end{array}$ & $99.4 \%$ & $99.1 \%$ & $100 \%$ \\
\hline Forced to change how payroll is reported & N/A & N/A & N/A \\
\hline $\begin{array}{l}\text { Forced to raise wages of workers in the same work } \\
\text { classification as those paid from city contracts }\end{array}$ & N/A & N/A & N/A \\
\hline $\begin{array}{l}\text { Forced to raise wages of workers in different work } \\
\text { classifications than those paid from city contracts }\end{array}$ & N/A & N/A & N/A \\
\hline Absorbed additional costs of complying with LWO & N/A & N/A & N/A \\
\hline \multicolumn{4}{|l|}{ Opinions about the city's living wage ordinance } \\
\hline Support the continuation of the LWO & $66 \%$ & & \\
\hline
\end{tabular}

*41 out of 57 companies surveyed or a response rate of $72 \%$.

$3 \%$ have experienced a reduction in absenteeism, turnover, accidents, and overtime pay. No company reports an improvement in company theft.

Given that the program has had no real effect on their performance and the fact that the mayor's office still has not publicized the names of member companies on his website (as promised), one wonders what value member companies see in the program. We inquired about this issue through another set of open-ended survey questions. We found that while most members $(63.4 \%)$ said they would support the continuation of the GBP program, over one-third said they would not or were unsure $(36.6 \%)$. When asked to explain, the latter responded:

I don't see any changes.

Does it have any impact?

Don't know if anyone changed because of it.

If it was gone, it would not be noticed.

It seems sleepy. 
Indeed, the lack of tangible benefits appears to be a primary source of uncertainty and doubt surrounding this voluntary living wage program. When asked what are the chief benefits of belonging to the GBP, the most frequent response was "none" (27\%). For instance, some answered:

Not certain.

Actually, we know of no benefits.

I have no idea of any benefits so far.

We have seen NO benefits of belonging to the program.

Even those who had a more positive assessment of the program were somewhat vague when it came to describing its benefits. For example, the next most frequently cited benefit was that "it shows a commitment to the city" (17\%).

While these results would appear to confirm the suspicion of some that the GBP program is more symbolic than real, it is important to note that members were able to offer concrete suggestions as to how it might be improved. For example, when asked what would it take to get more companies to join the program, participants suggested improved publicity (36\%), educating the business community about the importance of living wages (21\%), and demonstrating the actual benefits of membership (18\%). These suggestions are consistent with prior studies on voluntary approaches to regulation (e.g., Grant, 1997) that show that unless information about corporate behavior is effectively disseminated to citizens, and the latter are thus encouraged to act on that information as consumers, no real changes in corporate behavior are likely to occur.

\section{Summary and Conclusion}

This study examined two programs designed to improve economic conditions in a city where an estimated $40 \%$ of all jobs pay less than a living wage. Results from a survey of Tucson's living wage contractors show that the latter's resistance to the ordinance has been exaggerated by the local media. Findings also fail to support that notion that contractors oppose living wage ordinances because of the latter's financial and administrative burdens. Rather, they suggest that more plausible reasons might be found in contractors' inflexible managerial practices and their ideological biases. With respect to Tucson's GBP program, findings cast doubt on the idea that more voluntary programs, by themselves, can adequately address the problem of low wages. In particular, there is no evidence that companies began paying their workers living wages after joining the GBP program. Many participants express concern that the program lacks the types of incentives and publicity that are needed to change businesses' employment practices.

We would be careful to stress that our results cannot be generalized to all cities and thus are exploratory in nature. There are also several issues raised by our study that cannot be adequately addressed with just our survey data, such as the decisions involved in absorbing extra contract costs, the causes of efficiency gains, and so on. 
Nonetheless, our study is important in that it is one of the few to investigate the issue of living wages from the perspective of employers. It thus suggests how the living wage movement might be informed and advanced by examining the experiences of those actors who allegedly are most opposed to it. More generally, it alerts organizers to the need to specify the real sources of resistance to LWOs. The local media and the Chambers of Commerce will often suggest that contractors oppose LWOs because of the latter's onerous monetary and administrative requirement. For local organizers to let such claims go unchallenged may not only jeopardize the passage of LWOs, but also allow opponents to paint a false picture of a unified business community. By the same token, focusing on the financial and administrative reasons given against LWOs can divert organizers' and the public's attention from what may be the real source of opposition-sheer ideology.

Most importantly, our study demonstrates, for the first time, that the kind of voluntary approach to creating living wages that is championed by opponents is highly suspect. In one of the only cities with a voluntary living wage program, we discovered that its effects are at best symbolic. Our study thus shifts the burden of proof on those who would argue that such programs offer a viable alternative to mandatory living wage policies.

Don Grant is Professor of Sociology at the University of Arizona.

Mary Nell Trautner is a doctoral candidate in Sociology at the University of Arizona.

\section{Notes}

* Research for this study has been funded by the Arizona Institute for Public Life.

1. A living wage was defined at the time as $\$ 8.00$ an hour with medical benefits or $\$ 9.00$ an hour without medical benefits.

2. See Greenwald \& Stiglitz (1990) for debates among economists on the extent of imperfect information that exists with markets and its consequences for firm behavior.

3. Other examples are President Frank Delano Roosevelt's Blue Eagle program, which recognized companies that went the extra mile to hire workers during the Great Depression, and the Environmental Protection Agency's 33/50 program, which publicly acknowledges companies that cut their emissions of 33 particularly dangerous chemicals by half.

4. Two weeks after the initial mailing, reminders were sent to each of the nonrespondents. These were postcards that included our phone number and a sentence or two asking them to please mail back the survey form. The third stage, carried out two weeks later, involved mailing a new survey form, return envelope, and cover letter to each nonrespondent. This letter stressed the importance of hearing back from each business, as it was very important that all points of view were represented. Finally, two weeks after the third mailing, we sent a final postcard to each nonrespondent asking them again to return their survey forms by a specific date. Once the "deadline" had passed, we telephoned each of the nonrespondents to urge them one final time to return their survey forms, and offered to mail or fax new copies to anyone who had misplaced theirs. We also allowed businesses to fax their survey form back to us if that proved more convenient.

5. The characteristics of our random sample of GBP members match those of the entire population of members, which strengthens our confidence that the former is a good representation of the latter. (The City of Tucson provides information on a limited set of characteristics for each participating business.) 
Specifically, the average size of the businesses in our sample is 85 employees, compared to 89 for the population. Also, whereas sample businesses employed $85 \%$ of their workforces on a full-time basis, $81 \%$ of the population did the same. Nonprofit corporations make up $8.5 \%$ of our sample, and $7.2 \%$ of the population. We constructed confidence intervals for each of these three variables, and the population means for all three variables fall within their respective intervals, which provide further evidence that our sample is representative of the larger population from which they were drawn.

The $95 \%$ confidence intervals for the three variables are as follows: For number of employees, the interval is from 21.5 to 148.5 (the population mean is 89). For percentage of full-time workers, the interval is from $77 \%$ to $92 \%$ (the population mean is $85 \%$ ). And finally, for percentage of nonprofit organizations, the interval is from $1 \%$ to $17 \%$ (the population mean is $8.5 \%$ ).

6. To the extent that contractors are subject to ideological biases, it may also be that some contractors report few efficiency gains, not because they did not realize any, but they do not want their answers to be used to support the case for mandated wage policies.

7. Indeed, to oppose the LWO would be tantamount to saying that the mayor cannot be a member of his own living wage club.

\section{References}

Bernstein, J. 2000. Higher wages lead to more efficient service provision-the impact of living wage ordinances on the public contracting process. Washington DC.: Economic Policy Institute.

Card, D., and A. Krueger. 1999. Myth and measurement: The new economics of the minimum wage. Princeton, NJ: Princeton University Press.

Dillman, D. A. 1978. Mail and telephone surveys: The total design method. New York: John Wiley \& Sons.

_ 2000. Living wage policy: The basics. Employment policies. Employment Policies Institute.

Grant, D. 1997. Allowing citizen participation in environmental regulation: An empirical analysis of the effects of right-to-sue and right-to-know provisions on industry's toxic emissions. Social Science Quarterly 78:859-74.

Greenwald, B., and J. Stiglitz. 1990. Asymmetric information and the new theory of the firm: Financial constraints and risk behavior. American Economic Review 80:160-5.

Higuera, J. 2002. Living wage a godsend? Arizona Daily Star, March 23, D6-D7.

Kalleberg, A., B. Reskin, and K. Hudson. 2000. Bad jobs in America: Standard and nonstandard employment relations and job quality in the United States. American Sociological Review 65:256-78.

Kraut, K., S. Klinger, and C. Collins. 2000. Choosing the high road: businesses that pay a living wage and prosper. Boston, MA: Responsible Wealth.

Neumark, D., and S. Adams. 2000. Do living wage ordinances reduce urban poverty? National Bureau of Economic Research. Working Paper 7606, March.

Pollin, R. 2002. What is a living wage? Considerations from Santa Monica, California. Review of Radical Political Economics 34:267-73.

Pollin, R., and S. Luce. 1998. The living wage: Building a fair economy. New York, NY: W. W. Norton.

Reynolds, D. 1999. The living wage movement sweeps the nation. WorkingUSA (September-October):61-80.

Schoenberger, E. 2000. The living wage in Baltimore: Impacts and Reflections. Review of Radical Political Economics 32:428-36. 